\title{
John Kitsuse: A Sociologist in Everyday Life
}

\author{
Jack Katz
}

Published online: 18 March 2009

(C) The Author(s) 2009. This article is published with open access at Springerlink.com

As I try to pinpoint how John Kitsuse became an unending inspiration, I keep reflecting on my sense that John seemed to find the sociological career, not so much as something to become but as a vehicle for expressing who he was. He was a careful, sensitive man, and, while his publications mounted up to an impressive body of work, he was the rare sociologist whose contributions were significant in quality far more than what they measured in quantity. I don't recall any fluff in my reading of his work, and everything I absorbed from John, both from his writings and from the times I shared with him, penetrated deeply.

Even his sense of humor was sociological. If Goffman wrote about the dramaturgy of social life, John Kitsuse enacted it. People were always "laying" identities "on" others, a matter he noted with gestures and prosody that readily put people's expressions in 'scare' quotation marks. No doubt this came from disturbing experiences of finding himself to be taken to be a kind of person he did not recognize or embrace. I never pushed to find out what those experiences were; I assumed some were results of the racism he lived in his early years while others were more idiosyncratic. Maybe, were he not my senior, I would have asked him about the relationship between his intellectual sensibility and his biography, but I don't think so. I loved the delicate balance of his personality and would have hated to do anything to risk upsetting it even slightly.

Some memory flashes:

finding that he knew more Yiddish than I did;

being astonished at the efforts he went to in order to produce a multi-course Chinese meal;

being struck by the sincerity of his concerns when I was off to a winter holiday that would have me driving over icy Oklahoma roads; receiving unauthorized copies of secretly inscribed notes of a Harold Garfinkel lecture.

J. Katz ( $\triangle)$

UCLA, 264 Haines Hall, Los Angeles, CA 90051-1551, USA

e-mail: Jackkatz@soc.ucla.edu 
Then there are the memories of some of the best sociological instruction I have known. None occurred in the classroom. Here are three.

When I was doing my dissertation research, I related a particularly surrealistic scene from my fieldwork in which a local eviction court was operating as if the Marx brothers were in charge. I was not only encouraged by his apparent pleasure in my account. From such experiences I fixed a sense of what luminous data could be. In some way, ever since I have been capturing social life in order to tell stories to John.

One afternoon, when I showed up at his house to get a signature on something or other, I caught him with his hands in the dirt: he was in the process of transplanting. Somewhat histrionically, he marked each of the stages he went through with changes in his embodiment of the process: first playing at the task, then getting committed to it, then becoming involved with it, finally going on unnecessarily in order to ritualize finishing the process. The observation opened for me an endlessly fruitful appreciation of depth of involvement as the third dimension of social life.

One night at my apartment - maybe it was "the Sixties" or the atmosphere at Northwestern sociology, but John and Kathy did not use the line between student and professor to segregate social lives - I served a chocolate mousse on a large, round glass platter. After the first serving, most was gone and someone put a cigarette out on the glass. When I reached a spoon into the remains, John reacted with mock shock. His comment about the platter being polluted made clear to me that the sacred and the profane were not to be wrestled into understanding through working on Durkheim's texts but were all around us in the mystical underpinnings of the ordinariness of everyday life.

John inspired me to be a cook, a gardener, and a phenomenological sociologist, to honor craft in all, and to find intellectual motivation in the course of everyday life, not in academic sociology's status and reward systems. For all of this - and it adds up to a gift that is renewed daily-I remain profoundly grateful.

Open Access This article is distributed under the terms of the Creative Commons Attribution Noncommercial License which permits any noncommercial use, distribution, and reproduction in any medium, provided the original author(s) and source are credited. 